Abstracta Iranica Abstracta Iranica

Revue bibliographique pour le domaine irano-aryen

Volume 24 | 2003

Comptes rendus des publications de 2001

\title{
Tang Dai Jin Yin Qi Yanjiu. Beijing, 1999, 464 p. [Recherches sur l'argenterie et l'orfèvrerie Tang]
}

\author{
Étienne de La Vaissière
}

\section{(2) OpenEdition}

1 Journals

Édition électronique

URL : http://journals.openedition.org/abstractairanica/34251

DOI : 10.4000/abstractairanica.34251

ISSN : 1961-960X

\section{Éditeur :}

CNRS (UMR 7528 Mondes iraniens et indiens), Éditions de l'IFRI

\section{Édition imprimée}

Date de publication : 15 mai 2003

ISSN : 0240-8910

\section{Référence électronique}

Étienne de La Vaissière, «Tang Dai Jin Yin Qi Yanjiu. Beij ing, 1999, 464 p. [Recherches sur l'argenterie et l'orfèvrerie Tang] », Abstracta Iranica [En ligne], Volume 24 | 2003, document 44, mis en ligne le 05 janvier 2010, consulté le 25 septembre 2020. URL : http://journals.openedition.org/abstractairanica/ 34251 ; DOI : https://doi.org/10.4000/abstractairanica.34251

Ce document a été généré automatiquement le 25 septembre 2020.

Tous droits réservés 


\title{
Tang Dai Jin Yin Qi Yanjiu. Beijing, 1999, 464 p. [Recherches sur l'argenterie et l'orfèvrerie Tang]
}

\author{
Étienne de La Vaissière
}

Cet ouvrage fait une large part - un tiers - aux influences iraniennes dans l'art des Tang. Une table des matières, un long résumé en anglais et d'abondantes illustrations (dessins et photographies couleur et noir-et-blanc de bonne facture) peuvent permettre d'utiliser ce volume de manière plus aisée. On notera cependant que l'A. utilise essentiellement des articles chinois et japonais, et que des analyses de B. Marshak, par exemple, il ne semble connaître que le Sogdijskie serebro de 1971.

INDEX

Thèmes : 3.1. Est de l'Iran

\section{AUTEURS}

ÉTIENNE DE LA VAISSIÈRE

ENS - EPHE - Paris 